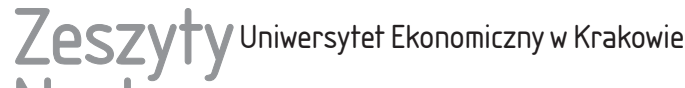 Naukowe
}

$7(955)$

ISSN 1898-6447

Zesz. Nauk. UEK, 2016; 7 (955): 57-69 DOI: 10.15678/ZNUEK.2016.0955.0704

Katarzyna Januszkiewicz

\section{Wykorzystanie testów psychologicznych w praktyce zarządzania}

\section{Streszczenie}

Stosowanie testów psychologicznych w obszarze zarządzania oparte jest na założeniu, że predyspozycje psychiczne są jednym z istotnych elementów dopasowania człowieka do jego zadań zawodowych. Procedury testowe najczęściej znajdują zastosowanie w sytuacji selekcji, doboru oraz rozwoju pracowników.

Celem artykułu jest charakterystyka testu psychologicznego jako narzędzia pomiaru wykorzystywanego w praktyce zarządzania. W opracowaniu przedstawiono historię pomiaru psychologicznego oraz współczesne praktyki stosowania testów w biznesie. Zwracając uwagę na potencjalne zagrożenia wynikające ze stosowania tych narzędzi, na zakończenie wskazano pożądane kierunki zmian regulacji w zakresie rozwiązań organizacyjnych.

Słowa kluczowe: testy psychologiczne, pomiar psychologiczny, standaryzacja, różnice indywidualne.

Klasyfikacja JEL: O15.

\section{Wprowadzenie}

Podstawą stosowania testów psychologicznych w obszarze zarządzania jest założenie, że predyspozycje psychiczne jednostki są obok wiedzy, umiejętności i kompetencji istotnym elementem dopasowania człowieka do jego zadań zawo-

Katarzyna Januszkiewicz, Uniwersytet Łódzki, Katedra Zarządzania, 90-237 Łódź, ul. Jana Matejki 22/26, e-mail: katarzynaj@uni.lodz.pl 
dowych, gwarantującym mu powodzenie i satysfakcję [Teoplitz-Wiśniewska 2011, s. 48]. Procedury testowe mogą być zatem stosowane w organizacji w sytuacji selekcji (podejmowania decyzji o zatrudnieniu pracownika), doboru (przypisania pracownika do odpowiedniego stanowiska pracy) i rozwoju (planowania ścieżki kariery) [The Standards for Educational... 2007].

Stosowanie testów psychologicznych w biznesie charakteryzuje się jednak pewną specyfiką. Narzędzia stworzone w ramach jednej dyscypliny wykorzystywane są na gruncie innej. Taka interdyscyplinarność nie jest dziś oczywiście niczym nowym, ale w przypadku tak szczególnym jak badanie cech psychologicznych człowieka ważna jest świadomość wyzwań stojących przed użytkownikami testów psychologicznych. Celem artykułu jest charakterystyka testu psychologicznego jako narzędzia pomiaru wykorzystywanego w praktyce zarządzania oraz wskazanie kierunku zmian najważniejszych regulacji odnoszących się do sposobu jego wykorzystania w biznesie.

\section{Pojęcie pomiaru i testu psychologicznego}

W psychologii pojęcie pomiaru odnosi się do wykorzystywania określonych procedur testowania $\mathrm{w}$ celu dokonania oceny wartości cech psychologicznych, w tym zdolności, zachowań czy indywidualnych cech ludzi [Guilford 1954, Hornowska 2005, Brzeziński 2011]. Pomiar często określany jest jako miara różnic indywidualnych z uwagi na charakter uzyskiwanych danych, większość stosowanych procedur pozwala bowiem oszacować, na ile dana jednostka jest odmienna lub podobna do innych ludzi pod jakimś względem [Gerrig i Zimbardo 2009, s. 282]. Wykorzystywane w określonych procedurach narzędzia służące do oceny indywidualnych właściwości człowieka (np. testy, miary zdolności i umiejętności, zadania symulacyjne, próbki pracy, schematy wywiadu) są zazwyczaj tworzone z myślą o ich stosowaniu zarówno w badaniach naukowych, jak i w praktyce zawodowej (np. organizacji, pracy klinicznej, edukacyjnej). Z uwagi na właściwości i możliwości aplikacyjne jednym z podstawowych narzędzi wykorzystywanych w obydwu obszarach są testy.

Testy w szerokim ujęciu definiowane są jako procedury lub metody, które służą badaniu lub ustalaniu występowania jakiegoś czynnika czy też zjawiska. W wąskim ujęciu traktowane są jako narzędzia badawcze zbudowane z puli wystandaryzowanych pozycji (np. pytań, bodźców lub zadań) ocenianych w sposób standardowy i używanych do badania i ewentualnego oszacowania wielkości różnic indywidualnych, np. w zakresie zdolności, umiejętności, kompetencji, skłonności, postaw, emocji [Anastasi i Urbina 1997, APA Dictionary... 2006, Cronbach 1990]. Ogólnie można zatem stwierdzić, że test wykorzystywany jest w różnych obszarach diagnozy psychologicznej jako narzędzie, które [Test User... 2016]: 
- pozwala diagnozować zachowania zarówno standardowe, jak i dysfunkcjonalne,

- posiada ściśle określoną procedurę prowadzenia badania i obliczania wyników,

- dostarcza wyników o pożądanych właściwościach psychometrycznych,

- jest miarą zachowania opartą na wnioskach wyciągniętych na podstawie analizy jego próbki i pozwala na jego jakościowy opis bądź systematyczną klasyfikację zmiennych.

Rozwój metodologii badań psychologicznych i związana z tym formalizacja procedur pomiaru i standaryzacja $\mathrm{w}$ zakresie stosowania testów przypada na początkowy okres rozwoju psychologii jako nauki na przełomie XIX i XX w. Warto jednak zaznaczyć, że na długo przed tym zanim zachodnia psychologia dostrzegła możliwości wynikające ze stosowania testów psychologicznych, różnorodne techniki pomiaru były wykorzystywane w starożytnych Chinach.

\section{Geneza i rozwój pomiaru psychologicznego}

Pierwsza wzmianka o zastosowaniu testów w celach zawodowych pojawia się w dokumentach sprzed 4 tys. lat i dotyczy urzędników służb cywilnych, którzy co 3 lata musieli wykazywać swoje kompetencje w trakcie egzaminu ustnego. Ponad 2 tys. lat później, za panowania dynastii Han, stosowano już pierwsze testy pisemne dla służb cywilnych, sprawdzające kompetencje urzędników w zakresie prawa, wojskowości, rolnictwa i geografii. Za czasów panowania dynastii Ming urzędnicy publiczni byli wybierani już na podstawie wyników uzyskiwanych na trzech etapach zobiektywizowanej procedury selekcji. Tylko 4\% najlepszych kandydatów z etapu pierwszego organizowanego lokalnie było dopuszczanych do etapu drugiego. Jego przebieg pozwalał sprawdzić szeroko rozumiane kompetencje kandydatów, ponieważ przez 5 dni i 5 nocy pisali oni eseje ze znajomości klasyków. Spośród tych, którzy zdali, 5\% było dopuszczonych do ostatniego etapu, przeprowadzanego w stolicy [Gerrig i Zimbardo 2009, s. 281].

Chińskie procedury selekcji zyskały rozgłos dzięki pracy brytyjskich dyplomatów i misjonarzy na początku XIX w., a ich upowszechnienie zbiegło się w czasie z rozwojem samej psychologii, która w początkowym okresie nie miała jeszcze ściśle określonych obszarów badań, a powstające narzędzia badawcze wykorzystywane były w różnych celach.

Współczesny pomiar psychologiczny w znacznej mierze opiera się na założeniach sformułowanych przez F. Galtona, Anglika, dalekiego krewnego K. Darwina, który starał się zastosować jego teorię ewolucji do badania ludzkich zdolności, a dokładniej - dociec istoty różnic indywidualnych w zakresie 
intelektu. Wnioski, do których doszedł, są dziś oceniane bardzo negatywnie ${ }^{1}$, ale przyjęte przez niego zasady dotyczące metodyki pomiaru inteligencji do dziś stanowią podstawę budowy testów psychologicznych również w innych obszarach. F. Galton na podstawie swoich badań wskazal, że:

- różnice w zakresie inteligencji mają charakter mierzalny (kwantyfikowalny) w kategorii poziomów inteligencji, co oznacza, że możliwe jest przypisanie wartości liczbowych w celu odróżnienia poziomów inteligencji poszczególnych osób;

- różnice występujące między ludźmi obrazuje tzw. krzywa dzwonowa, mają one charakter rozkładu normalnego (wyniki większości ludzi umieszcza się pośrodku, natomiast na krańcach - mniejszościowe wyniki osób genialnych lub upośledzonych umysłowo);

- pomiar inteligencji czy zdolności umysłowych może być dokonany za pomocą obiektywnych testów, w których na każde pytanie można udzielić tylko jednej poprawnej odpowiedzi;

- stopień, w jakim dwa zestawy wyników testów są ze sobą powiązane, może być wskazany dzięki procedurze statystycznej, określonej przez F. Galtona jako korelacja [Gerrig i Zimbardo 2009, s. 282].

Warto zaznaczyć, że pierwsze testy psychologiczne dotyczyły pomiaru inteligencji i powstawały głównie w odpowiedzi na potrzeby związane z wydarzeniami historycznymi i oczekiwaniami społeczno-politycznymi ${ }^{2}$. Od psychologii oczekiwano, że dostarczy ona wskazań, a nawet konkretnych narzędzi umożliwiających poprawienie jakości życia całego społeczeństwa [Zeidler 2011, s. 80]. Możliwość równoczesnego przebadania stosunkowo prostym narzędziem bardzo dużej grupy osób nie tylko przesądziła o popularności testów jako narzędzi diagnozy, ale również przyczyniła się do przyjęcia niejako a priori założenia, że

${ }^{1}$ F. Galton był autorem tezy o dziedziczeniu geniuszu i ograniczonym wpływie środowiska na kształtowanie inteligencji. Dlatego też uważał, że podstawą polityki publicznej powinno być przyjęcie założenia o ludziach genetycznie wyższych i niższych. Był inicjatorem ruchu eugenicznego dążącego do udoskonalenia rasy przez wspieranie biologicznie lepszych ludzi i „stopniowego ograniczania rasy niższej”. Poglądy te zostały w późniejszych latach wykorzystane przez nazistów, ale ich siła oddziaływania jest tak duża, że również dziś znajdują swoich zwolenników [Gerrig i Zimbardo 2009, s. 284].

2 Rozwój metod testowych przebiegał niemal równocześnie w różnych częściach świata. W Europie warto wspomnieć o przeprowadzonych na początku XX w. pionierskich badaniach dotyczących inteligencji dzieci, które były odpowiedzią A. Bineta na wezwanie francuskiego ministra oświaty, dążącego do stworzenia bardziej skutecznych metod nauczania dzieci upośledzonych. Podobne testy były wykorzystywane w Stanach Zjednoczonych do identyfikowania, dokumentowania i klasyfikowania dorosłych imigrantów i ich dzieci w wieku szkolnym. Gdy rozpoczęła się I wojna światowa, duża grupa ochotników wymagała stworzenia metody powalającej na szybkie określenie zdolności poszczególnych osób. Nowe niewerbalne grupowe testy zdolności umysłowych zostały wówczas zastosowane do oceny ponad 1,7 mln rekrutów (szerzej na ten temat zob. [Gerrig i Zimbardo 2009, Zeidler 2011]). 
inteligencja może różnicować ludzi pod względem zdolności przywódczych oraz innych społecznie ważnych cech. Doprowadziło to w konsekwencji do rozpowszechnienia stosowania testów w oświacie i przemyśle jako stosunkowo niedrogiej, szybkiej i demokratycznej drogi do weryfikacji i selekcji [Gerrig i Zimbardo 2009, s. 286]. Obecnie testy jako narzędzia diagnozy psychologicznej oprócz inteligencji obejmują również wiele innych zmiennych, co pozwala na ich stosowanie w szeroko rozumianej praktyce badawczej, w tym również w obszarze zarządzania.

\section{Testy jako narzędzie diagnozy w obszarze zarządzania}

W 2009 r. Europejska Federacja Towarzystw Psychologicznych (European Federation of Psychologists' Associations - EFPA) przeprowadziła badania na próbie 12606 psychologów z 17 europejskich krajów (w tym z Polski) na temat testów i praktyki ich stosowania [Evers i in. 2012, s. 300]. W Polsce jedynie 9\% respondentów stanowili psychologowie pracujący w organizacjach. Ich wyniki w sposób istotny różniły się od odpowiedzi psychologów zatrudnionych w innych obszarach praktyki psychologicznej [Jaworowska 2009, s. 8], co wskazuje na pewną specyfikę wykorzystania narzędzi diagnozy psychologicznej w organizacjach.

W celu uzyskania pełniejszego obrazu stosowania testów w obszarze zarządzania Pracownia Testów Psychologicznych (PTP) oraz Instytut Rozwoju Biznesu przeprowadziły badanie skierowane do osób zatrudnionych w organizacjach, które w ramach swojej działalności stosują testy. Warto przy tym zaznaczyć, że w próbie 112 osób, które odpowiedziały na pytania zawarte w ankiecie, znaleźli się zarówno psychologowie (71\%), jak i absolwenci innych kierunków (zarządzania, socjologii, ekonomii, pedagogiki) [Jaworowska 2011, s. 9].

W badanych organizacjach testy wykorzystywane były najczęściej w procesie rekrutacji i selekcji (zarówno zewnętrznej, jak i wewnętrznej), natomiast najrzadziej stosowano je jako narzędzie wspierające przy planowaniu zwolnień monitorowanych. Co ciekawe, przedmiotem badań były jednak częściej tzw. kompetencje miękkie niż inteligencja ogólna czy zdolności (tabela 1)3.

3 Jeśli weźmiemy pod uwagę deklarowane przez respondentów obszary, w których wykorzystywane są testy (przede wszystkim rekrutacja i selekcja), przewaga w badaniu kompetencji miękkich może zdumiewać. Szczególnie w świetle rezultatów metaanalizy, które wskazują, że zmienną pozwalającą najlepiej przewidzieć szeroko rozumiany sukces zawodowy jest inteligencja ogólna, przy czym związek między poziomem wykonania pracy a poziomem inteligencji ogólnej dotyczy wszystkich zawodów, choć jest silniejszy dla zawodów wymagających wykonywania bardziej złożonych zadań [Czarnota-Bojarska 2009]. 
Tabela 1. Przedmiot diagnozy przeprowadzonej za pomocą testów w polskich organizacjach (badanie PTP i IRB; ankieta HR: $\mathrm{N}=112$; 2010)

\begin{tabular}{|l|c|}
\hline \multicolumn{1}{|c|}{ Zmienna } & Odpowiedzi „tak” (w \%) \\
\hline Osobowość & 88 \\
\hline Kompetencje kierownicze & 72 \\
\hline Umiejętności społeczne & 61 \\
\hline Temperament & 52 \\
\hline Odporność na stres & 52 \\
\hline Inne kompetencje zawodowe & 52 \\
\hline Inteligencja lub zdolności & 51 \\
\hline Motywacja & 46 \\
\hline Wiedza zawodowa & 38 \\
\hline Inteligencja emocjonalna & 34 \\
\hline Kreatywność & 29 \\
\hline Inne & 9 \\
\hline
\end{tabular}

Źródło: [Jaworowska 2011, s. 13].

Pomiar każdej z wymienionych zmiennych możliwy jest za pomocą wielu narzędzi badawczych; ich wybór może być oparty na bardzo zróżnicowanych kryteriach, począwszy od merytorycznych, po finansowe. Odpowiedzi udzielane przez osoby badane mogą świadczyć o wysokiej świadomości respondentów na temat znaczenia własności psychometrycznej testów dla jego wartości ${ }^{4}$, ale autorzy raportu są dosyć powściągliwi w wyciąganiu tak daleko idących wniosków. Szczególnie w kontekście parametrów testów wskazywanych jako najczęściej stosowane (m.in. NEO-FFI, Testy Matryc Ravena, KKS), dla których rzetelność skal w diagnozie indywidualnej jest niewystarczająca, a dane dotyczące trafności nie odnoszą się do zastosowań w rekrutacji i selekcji [Jaworowska 2011, s. 14-18].

Prawidłowe wykorzystanie testów psychologicznych wymaga przestrzegania określonych standardów. Większość z osób biorących udział w badaniach była psychologami, więc formalnie posiadali przygotowanie do stosowania testów psychologicznych. Niezależnie jednak od wykształcenia respondenci wskazywali, że podczas procedury testowania dochodzi do błędów i nieprawidłowości (tabela 2).

${ }^{4}$ Najczęściej wskazywane powody w kolejności to: trafność, rzetelność, normy, koncepcja leżąca u podstaw testu, cena, możliwość automatycznego wygenerowania raportu, popularność na rynku, autor [Jaworowska 2011, s. 16]. 
Tabela 2. Błędy i nieprawidłowości w stosowaniu testów w polskich organizacjach (badanie PTP i IRB; ankieta HR: $\mathrm{N}=112 ; 2010$ )

\begin{tabular}{|c|c|c|c|c|}
\hline \multirow[b]{2}{*}{ Błędy i nieprawidłowości } & \multicolumn{3}{|c|}{ Odpowiedzi (w \%) } & \multirow[b]{2}{*}{$\begin{array}{l}\text { Brak odpo- } \\
\text { wiedzi } \\
\quad(w \%)\end{array}$} \\
\hline & $\begin{array}{c}\text { nigdy lub } \\
\text { prawie } \\
\text { nigdy }\end{array}$ & zdarza się & często & \\
\hline $\begin{array}{l}\text { Nielegalne kopiowanie materiałów } \\
\text { testowych }\end{array}$ & 48 & 44 & 8 & - \\
\hline $\begin{array}{l}\text { Wykorzystanie testów o nieznanych } \\
\text { własnościach psychometrycznych }\end{array}$ & 29 & 46 & 21 & 4 \\
\hline Stosowanie testów bez polskich norm & 23 & 51 & 24 & 2 \\
\hline $\begin{array}{l}\text { Zbyt daleko idące interpretacje wyni- } \\
\text { ków testowych }\end{array}$ & 15 & 51 & 32 & 2 \\
\hline $\begin{array}{l}\text { Wykorzystanie testów o nieznanym } \\
\text { statusie prawnym }\end{array}$ & 34 & 52 & 12 & 2 \\
\hline $\begin{array}{l}\text { Stosowanie testów bez odpowiednich } \\
\text { kwalifikacji }\end{array}$ & 23 & 53 & 22 & 2 \\
\hline
\end{tabular}

Źródło: [Jaworowska 2011, s. 23].

Wskazywane przez respondentów odstępstwa można przyporządkować do dwóch jakościowo odmiennych kategorii. Pierwsza związana jest z nieprzestrzeganiem prawa, w tym z naruszaniem praw autorskich, co szczególnie w przypadku instytucjonalnego korzystania $z$ technik badawczych nie powinno mieć miejsca. Druga kategoria błędów, częściej wskazywana, dotyczy nieprzestrzegania zasad dotyczących stosowania testów psychologicznych. Nasuwa się zatem pytanie, czy przyczyn takiego stanu rzeczy należy upatrywać w lekceważeniu zaleceń i świadomym obniżaniu standardów wykonywanej pracy, czy też w niewiedzy lub niewystarczającym przygotowaniu merytorycznym osób korzystających z tych narzędzi diagnozy. Trudno oczywiście oczekiwać w tym przypadku prostej odpowiedzi, zwłaszcza w sytuacji gdy obraz wyłaniający się z zaprezentowanych badań nie jest jednoznaczny. $Z$ jednej strony respondenci mają świadomość wartości własności psychometrycznych testu, z drugiej jednak, jakby nie bacząc na to, dopuszczają się pewnych nadużyć. Dlatego też choć badana próba nie jest reprezentatywna dla całej populacji osób wykorzystujących testy w praktyce zarządzania, warto dokonać analizy zasad regulujących stosowanie testów w Polsce.

\section{Zasady stosowania testów psychologicznych}

$\mathrm{Z}$ uwagi na charakter danych uzyskiwanych w procedurze pomiaru stosowanie testów psychologicznych w procesie zarządzania zasobami ludzkimi 
wymaga uwzględnienia trzech perspektyw: merytorycznej, prawnej, i etycznej [Teoplitz-Wiśniewska 2011, s. 49].

Regulacje prawne w zakresie wykorzystania diagnozy psychologicznej dla określenia predyspozycji psychicznych odnoszą się tylko do konkretnych czynności zawodowych, dla których wymagane są specyficzne kwalifikacje (np. żołnierz, policjant, pilot) $)^{5}$. Stosowanie testów psychologicznych w szerszym ujęciu (zgodnie ze wskazanymi we stępie obszarami) nie jest natomiast regulowane żadnymi przepisami. Mamy zatem obecnie do czynienia z sytuacją, w której z jednej strony pozyskiwane są dane wrażliwe, bo takimi są z pewnością wyniki testów psychologicznych, z drugiej zaś istnieje dowolność w postępowaniu badawczym. Próby uporządkowania i opanowania tego swoistego chaosu podejmowane są przez organizacje o zasięgu krajowym i międzynarodowym. Europejskim liderem w opracowywaniu standardów i zasad postępowania w procedurze testowej jest European Federation of Psychologists' Associations, w Polsce działania takie podjęte zostały przez Polską Grupę Ekspercką EFPA Euro Test - WO. Kultura stosowania testów bardzo dynamicznie się rozwija i trudno oczekiwać, by same regulacje prawne czy przepisy zawarte w kodeksach były wystarczającym rozwiązaniem. Bardzo ważna w tym przypadku jest etyka zawodowa, dla której podstawą powinno być rzetelne przygotowanie merytoryczne osób odpowiedzialnych za politykę personalną niezależnie od specjalizacji.

Pracownicy działów HR to nie tylko psychologowie, są wśród nich również absolwenci zarządzania, socjologii i innych pokrewnych kierunków. Grupa użytkowników testów jest zatem bardzo zróżnicowana pod względem przygotowania merytorycznego, co doprowadziło do tego, że konieczne stało się określenie jednoznacznych reguł dotyczących możliwości dostępu do tego narzędzia. W 2010 r. Zarząd Główny Polskiego Towarzystwa Psychologicznego wznowił działalności Komisji do spraw Testów Psychologicznych, której celem była kategoryzacja testów, w szczególności zaś wskazanie, jakie kwalifikacje powinny mieć osoby posługujące się poszczególnymi testami. W ocenie Komisja brała pod uwagę [Kategoryzacja testów... 2012]:

- konsekwencje użycia danego testu dla osoby badanej - testy mające duże konsekwencje dla osoby badanej to takie, których wyniki mogą być podstawą decyzji wpływających na zmianę losu jednostki (orzecznictwo, opinie mające konsekwencje prawne);

- diagnozowane obszary - w jakim stopniu użycie danego testu wymaga pogłębionej wiedzy psychologicznej oraz jaki jest charakter zmiennej. Jako

5 Ten rodzaj diagnozy przeprowadzany jest przez psychologa posiadającego dodatkowe kompetencje i uprawnienia. Badania testowe stanowią w tym przypadku jeden z elementów procedury, która kończy się orzeczeniem o możliwości wykonywania przez kandydata danego rodzaju zadań. Jest to jednak specyficzny rodzaj diagnozy. 
Tabela 3. Kategoryzacja testów (testy wydawnictw Pracownia Testów Psychologicznych PTP oraz ERDA)

\begin{tabular}{|c|l|l|l|c|}
\hline $\begin{array}{c}\text { Kate- } \\
\text { goria } \\
\text { testów }\end{array}$ & Przeznaczenie testów & Wymagane kwalifikacje & $\begin{array}{l}\text { Wymagane dokumenty/ } \\
\text { informacje }\end{array}$ & $\begin{array}{c}\text { Liczba } \\
\text { pozycji } \\
\text { w danej } \\
\text { kategorii }\end{array}$ \\
\hline I & Tylko dla psychologów & $\begin{array}{l}\text { Ukończone studia magi- } \\
\text { sterskie z psychologii. } \\
\text { Osoby, które mają tytuł } \\
\text { doktora psychologii, } \\
\text { a nie ukonczyły studiów } \\
\text { psychologicznych, mogą } \\
\text { kupować testy wyłącznie } \\
\text { do celów naukowych }\end{array}$ & $\begin{array}{l}\text { Dyplom ukończenia stu- } \\
\text { diów psychologicznych. } \\
\text { Dyplom doktorski } \\
\text { wraz z oświadczeniem } \\
\text { informującym, że test } \\
\text { będzie stosowany tylko } \\
\text { do celów naukowych }\end{array}$ & 51 \\
\hline II & $\begin{array}{l}\text { Dla psychologów; } \\
\text { dla innych profesjona- } \\
\text { listów po ukończonym } \\
\text { szkoleniu }\end{array}$ & $\begin{array}{l}\text { Ukończone studia } \\
\text { wyższe magisterskie } \\
\text { lub podyplomowe } \\
\text { na kierunkach, które } \\
\text { przygotowują do pracy } \\
\text { z ludźmi (nauki peda- } \\
\text { gogiczne, społeczne } \\
\text { i medyczne) oraz ukoń- } \\
\text { czone szkolenie według } \\
\text { programu zaakceptowa- } \\
\text { nego przez PTP }\end{array}$ & $\begin{array}{l}\text { Dyplom ukończenia } \\
\text { studiów wyższych } \\
\text { magisterskich lub pody- } \\
\text { plomowych z zakresu } \\
\text { nauk pedagogicznych, } \\
\text { społecznych lub } \\
\text { medycznych (w zależ- } \\
\text { ności od rodzaju testu) } \\
\text { oraz certyfikat ukończe- } \\
\text { nia szkolenia zaakcepto- } \\
\text { wanego przez PTP }\end{array}$ & 18 \\
\hline III & $\begin{array}{l}\text { Dla psychologów; } \\
\text { dla innych profesjona- } \\
\text { listów }\end{array}$ & $\begin{array}{l}\text { Ukończone studia } \\
\text { wyższe magisterskie lub } \\
\text { podyplomowe na kie- } \\
\text { runkach, które przygoto- } \\
\text { wują do pracy z ludźmi } \\
\text { (nauki pedagogiczne, } \\
\text { społeczne i medyczne) } \\
\text { W przypadku psycho- } \\
\text { terapeutów - dowolne } \\
\text { studia wyższe }\end{array}$ & $\begin{array}{l}\text { Dyplom ukończenia } \\
\text { studiów wyższych } \\
\text { magisterskie lub pody- } \\
\text { plomowych z zakresu } \\
\text { nauk pedagogicz- } \\
\text { nych, społecznych lub } \\
\text { medycznych. W przy- } \\
\text { padku psychoterapeutów } \\
\text { - dyplom ukończenia } \\
\text { studiów wyższych oraz } \\
\text { certyfikat psychotera- } \\
\text { peutyczny }\end{array}$ & 43 \\
\hline
\end{tabular}

Źródło: [Kategoryzacja testów... 2012].

przykład zmiennej wrażliwej przyjęto inteligencję, a mało wrażliwej - zainteresowania;

- kompetencje psychometryczne - w jakim stopniu poprawne użycie danego testu (ocena i interpretacja wyników) wymaga dogłębnej znajomości psychometrii; czy możliwe jest procedowanie na podstawie informacji zawartych w podręczniku; 
- trudność w stosowaniu - czy poprawne użycie testu wymaga specyficznych kompetencji nabywanych w toku studiów lub szkoleń, czy też wystarczy znajomość instrukcji.

W wyniku kategoryzacji dostęp do testów będących w dyspozycji największego w Polsce depozytariusza narzędzi diagnozy psychologicznej został rozszerzony i obecnie z zasobów Pracowni Testów Psychologicznych na określonych zasadach mogą korzystać również osoby nielegitymujące się dyplomem psychologa (tabela 3). Co ciekawe, najwięcej testów rekomendowanych do wykorzystania przez pracowników działów HR lub doradców zawodowych należy do drugiej kategorii, również tych umieszczonych tam na życzenie autora ${ }^{6}$.

Rozwiązania przyjęte przez Polskie Towarzystwo Psychologiczne uznać należy za pierwszy krok na drodze do stworzenia standardów wykorzystywania testów w biznesie. Można jednak zauważyć wyraźny kierunek tych działań, które zmierzają do adaptacji i wdrożenia w Polsce europejskich projektów afiliowanych przez EFPA, do których należą [Documents... 2016]:

- EFPA meta-code of Ethic - dokument zawierający podstawowe wytyczne stosowania testów takie jak respektowanie praw drugiego człowieka czy dbałość o odpowiedni poziom kompetencji;

- Test Review - ranking testów uwzględniający jakość narzędzi badawczych;

- Euro Test - WO - certyfikat, który pozwala zdobyć kompetencje osobom chcącym zrobić specjalizację z zakresu stosowania testów w biznesie;

- EuroPsy - projekt skierowany wyłącznie do psychologów, umożliwiający im zdobycie dodatkowej wiedzy i kompetencji.

Nawiązując zatem do wymienionych na wstępie tego punktu trzech perspektyw, można stwierdzić, że prawne, etyczne i merytoryczne aspekty stosowania testów psychologicznych w biznesie są ze sobą mocno powiązane. Najważniejsza zmiana, która wydaje się odpowiedzią na potrzeby rynku, dotyczy włączenia do grupy użytkowników testów również osób nieposiadających wykształcenia psychologicznego. Kompetentnym użytkownikiem testu nie musi być bowiem tylko psycholog - to przede wszystkim profesjonalista, który przechowuje i dostarcza materiały testowe, odpowiada za wybór metod testowych, przeprowadza badania, ocenia i interpretuje wyniki, przygotowuje raport i udziela informacji zwrotnych, na podstawie wyników testowych doradza badanym, tworzy testy bądź aktualizuje ich wersje [Test User... 2016]. Oczywiście regulatorem wszelkich działań powinna pozostać etyka, która nakazuje zachowanie należytej staranności w diagnozie zarówno psychologom, jak i osobom niebędącym psychologami.

${ }^{6}$ Dodatkowym kryterium kwalifikacji była decyzja autora testu. Niektórzy z nich, kierując test do publikacji, zastrzegali, że ma być dostępny nie tylko dla psychologów. Testy te oznaczono w spisie PTP literą A. 


\section{Podsumowanie}

Stosowanie testów psychologicznych w zarządzaniu wydaje się pożądaną praktyką. Wspieranie decyzji kadrowych wystandaryzowanymi, zobiektywizowanymi narzędziami może pozytywnie wpływać nie tylko na jakość działań personalnych w ramach organizacji, ale również na rozwój samego pracownika, który ma szanse uzyskać informację na temat swoich predyspozycji i możliwość lokowania ich na tle populacji (w przypadku odniesienia do norm). Dodatkową zaletą stosowania testów jest ich elitaryzm. Wynikający z ochrony prawnej, ale również, a może nawet przede wszystkim z solidarności środowiska, ograniczony dostęp do narzędzi diagnozy sprawia, że osoby postronne nie mają możliwości przygotowania się do badania, a narzędzie zachowuje swoją rzetelność.

Nie sposób jednak pominąć w tym miejscu pewnych ograniczeń wynikających z właściwości samych testów. Często są to narzędzia tworzone z myślą o badaniach naukowych, a zatem ich trafność szacowana jest na podstawie prób ogólnych, podczas gdy funkcjonowanie zawodowe charakteryzuje się pewną specyfiką. Ponadto znaczenie niektórych zmiennych psychologicznych jest silnie uwarunkowane sytuacyjnie, stąd też oceniając kreatywność, należy zwrócić uwagę, czy dotyczy ona kandydata na stanowisko księgowego, czy pracownika działu reklamy. Dla organizacji międzynarodowych kolejnym wyzwaniem może być ujednolicenie narzędzi stosowanych $\mathrm{w}$ ramach całej grupy wymagające odpowiedniej walidacji i adaptacji kulturowej.

Biorąc zatem pod uwagę zarówno zalety, jak i wady stosowania testów psychologicznych w biznesie, należy uznać, że przedstawione w niniejszym opracowaniu rozwiązania w zakresie wypracowania standardów środowiskowych wydają się zmierzać w dobrym kierunku. Możliwość obiektywnej oceny zarówno użytkowników testów (np. Euro Test - WO), jak i samych narzędzi (np. Test Review) zmniejsza ryzyko popełnienia błędu, a tym samym wpływa na jakość podejmowanych działań. Niezależnie jednak od regulacji najważniejszy jest zdrowy rozsądek, prawo zwyczajowe i silna kultura organizacyjna, która przez wartości i normy kształtować będzie właściwe postawy w zakresie stosowania testów w biznesie.

\section{Literatura}

Anastasi A., Urbina S. [1997], Psychological Testing, 7th ed., Prentice Hall, Upper Saddle, NJ.

APA Dictionary of Psychology [2006], American Psychological Association, Washington, DC.

Brzeziński J. [2011], Metodologia badań psychologicznych, Wydawnictwo Naukowe PWN, Warszawa. 
Cronbach L.J. [1990], Essentials of Psychological Testing, 5th ed., Harper Collins, New York.

Czarnota-Bojarska J. [2009], Selekcja zawodowa. Przygotowanie, prowadzenie i podstawowe metody, Pracownia Testów Psychologicznych Polskiego Towarzystwa Psychologicznego, Warszawa.

Documents, European Federation of Psychologists' Associations [2016], http://www.efpa. com.pl/?page_id=17 (data dostępu: 20.04.2016).

Evers A., Muñiz J., Bartram D., Boben D., Egeland J., Fernández-Hermida J.R., Frans Ö., Gintiliené G., Hagemeister C., Halama P., Iliescu D., Jaworowska A., Jiménez P., Manthouli M., Matesic K., Schittekatte M., Sümer H.C., Urbánek T. [2012], Testing Practices in the 21st Century: Developments and European Psychologists' Opinions, „European Psychologist”, vol. 17(4), https://doi.org/10.1027/1016-9040/a000102.

Gerrig R.J., Zimbardo P.G. [2009], Psychologia i życie, Wydawnictwo Naukowe PWN, Warszawa.

Guilford J.P. [1954], Theory of Psychological Tests [w:] J.P. Guilford, Psychometric Methods, 2nd ed., McGraw-Hill, New York.

Hornowska E. [2005], Testy psychologiczne. Teoria i praktyka, Wydawnictwo Naukowe Scholar, Warszawa.

Jaworowska A. [2009], Co polscy psychologowie sądza o testach?, „Nowiny Psychologiczne", nr 1 .

Jaworowska A. [2011], Testy w biznesie - wyniki ankiety [w:] Testy w biznesie. Standardy i praktyka, red. T. Szustrowa, Pracownia Testów Psychologicznych Polskiego Towarzystwa Psychologicznego, Warszawa.

Kategoryzacja testów psychologicznych [2012], Pracownia Testów Psychologicznych Polskiego Towarzystwa Psychologicznego, http://www.ptp.org.pl/modules.php?name $=$ News \&file $=$ article \&sid=463 (data dostępu: 5.05.2016).

The Standards for Educational and Psychological Testing [2007], American Educational Research Association, American Psychological Association, National Council on Measurement in Education, Washington, DC.

Teoplitz-Wiśniewska M. [2011], O etyce w stosowaniu testów w biznesie [w:] Testy w biznesie. Standardy i praktyka, red. T. Szustrowa, Pracownia Testów Psychologicznych Polskiego Towarzystwa Psychologicznego, Warszawa.

Test User Standards, European Federation of Psychologists' Associations [2016], http:// www.efpa.eu/professional-development/test-and/testing (data dostępu: 25.04.2016).

Zeidler W. [2011], Kwestionariusze w psychologii: kierunki rozwoju i pierwsze filiacje teoretyczne [w:] Kwestionariusze w psychologii. Postepy, zastosowania, problemy, red. W. Zeidler, Wydawnictwo Vizja Press \& IT, Warszawa.

\section{Psychological Testing in Business \\ (Abstract)}

The basis for using psychological testing in management is the assumption that the individual's psychological predisposition is an essential element used to match individuals to professional tasks. The test procedures are therefore used most commonly in organisations in three situations: selecting employees to hire, assigning them to an appropriate job, and development and career planning. 
The article presents psychological tests as a tool for use in business practice. It describes the history of psychological measurement and presents the results of research on the use of testing in organisations in the twenty-first century. The final part of the article presents the main directions of change in the rules governing the use of testing in business and identifies areas that require special sensitivity.

Keywords: psychological tests, psychological measurement, standarisation, individual differences. 